\title{
Comparison of Total Phenolic Content and Total Antioxidant Activity in Local Red Wines Determined by Spectrophotometric Methods
}

\author{
Ebru Büyüktuncel'1, Esra Porgalı1, Cemil Çolak ${ }^{2}$ \\ ${ }^{1}$ Department of Analytical Chemistry, Faculty of Pharmacy, University of Inonu, Malatya, Turkey \\ ${ }^{2}$ Department of Biostatistics, Faculty of Medicine, Inonu University, Malatya, Turkey \\ Email: saliha.buyuktuncel@inonu.edu.tr
}

Received 22 June 2014; revised 26 July 2014; accepted 7 August 2014

Copyright (C) 2014 by authors and Scientific Research Publishing Inc.

This work is licensed under the Creative Commons Attribution International License (CC BY). http://creativecommons.org/licenses/by/4.0/

(c) (i) 0 pen Access

\begin{abstract}
In this study, the antioxidant activity of local red wines was determined by four different analytical methods: 1,1-diphenyl-2-picrylhydrazyl (DPPH) radical scavenging assay, 2,2'-azino-bis-(3ethylbenzothiazoline-6-sulfonic acid) (ABTS ${ }^{+}$) radical cation decolourisation, ferric reducing/antioxidants power (FRAP) and cupric ion reducing capacity in the presence of neocuproine (CUPRAC) for the evaluation of reducing power (PR). They were correlated with the total phenolic content (TPC) determined with the Folin-Ciocalteu's reagent using gallic acid as a standard. The total polyphenol concentration was found to vary from 2599.90 to $4846.57 \mathrm{mg} / \mathrm{L}$ gallic acid equivalents (GAE). The total antioxidant activity determined by DPPH, ABTS, FRAP and CUPRAC methods was found to vary from 7.49 - $15.93 \mathrm{mmol} / \mathrm{L}, 12.02-24.73 \mathrm{mmol} / \mathrm{L}, 12.65-27.68 \mathrm{mmol} / \mathrm{L}$ and 13.19 $31.07 \mathrm{mmol} / \mathrm{L}$, respectively. The total phenolic contents of red wine samples exhibited a good correlation $(\mathrm{p}<0.01)$ with antioxidant properties.
\end{abstract}

\section{Keywords}

Red Wine, Antioxidant Activity, Total Phenolic Content, DPPH, ABTS, FRAP, CUPRAC

\section{Introduction}

Antioxidants are substances that, at low concentrations, prevent or retard the oxidation of easily oxidisable biomolecules such as lipids, proteins or DNA. They counteract free radicals and thus prevent oxidative damage [1] 
[2]. There are two basic categories of antioxidants, namely, synthetic and natural. The interest of natural antioxidants has increased in recent years because of their presumed safety and potential nutritional and therapeutical effects [3]. Epidemiological studies indicated that a higher level of natural antioxidants (vitamins, carotenoids, phenolics) in human everyday diet can protect against cardiovascular diseases, cataract, cancer and aging-related disorders [4]. Among natural antioxidants, red wine has attracted particular interest due to a high content of biologically active compounds [3]. Phenolic compounds are one of the most important quality parameters of wines, and they contribute to organoleptic characteristics such as color, astringency, and bitterness [5]. These compounds are also active in biochemical processes and have nutraceutical effects on human health, including antimicrobial, anticarcinogenic, and antioxidant properties [6]. Consequently, numerous papers have focused on the determination of antioxidant capacities of wines and correlation with their polyphenol content [5]-[12].

Several in vitro methods have been developed to measure antioxidant capacities of food, beverages and biological samples. The most commonly used antioxidant capacity assays were 1,1-diphenyl-2-picrylhydrazyl radical (DPPH·) assay [13], 2,2-azino-di-(3-ethylbenzothialozine-sulphonic acid) (ABTS) assay [14], ferric ion reducing antioxidant power (FRAP) assay [15] [16], cupric ion reducing capability (CUPRAC) assay [17] and oxygen radical absorbance capacity (ORAC) assay [18] [19]. These methods differ from each other in terms of their assay principles and reaction conditions. Single assay will not accurately reflect all antioxidants. Therefore it is recommended that at least two or all of these assays be combined to provide a full profile of antioxidant capacity of foodstuff [20].

The main objective of this study was to determine the polyphenolic content and antioxidant capacity of local wine samples and to compare the antioxidant capacity of these samples applying four most widely used spectrophotometric methods: DPPH, ABTS, FRAP, CUPRAC and to estimate correlation of antioxidant capacities with total phenolics.

\section{Material and Methods}

\subsection{Wine Samples}

8 red wine samples were purchased from local stores in Elazığ and Malatya (Table 1). Samples were opened, protected against sunlight and stored at $4^{\circ} \mathrm{C}$. Analyses were carried out within a few days. Each wine was analyzed 5 times.

\subsection{Chemicals}

Gallic acid, Folin-Ciocalteu reagent, 2,2-diphenyl-1-picrylhydrazyl radical (DPPH) and 2,2'-azino-bis (3-ethylbenzothiazoline-6-sulphonic acid)diammonium salt (ABTS) were purchased from Sigma-Aldrich. Trolox (6hydroxy-2,5,7,8-tetramethylchromane-2-carboxylic acid) and 2,4,6-tris(2-pyridyl)-s-triazine (TPTZ) were purchased from Fluka. Copper(II)chloride, iron(III)chloride, potassium peroxodisulfate, sodium acetate, ammonium acetate, sodium carbonate were obtained from Merck. 2,9-dimethyl-1,10-phenanthroline was from Acros Organics. All solvents and reagents that are used in this study were HPLC or of analytical grade.

Table 1. The wine samples tested.

\begin{tabular}{|c|c|c|c|c|c|}
\hline Wine samples & Grape variety & Year & $\mathbf{p H}$ & Alcohol content \% & Location \\
\hline 1 & Kalecik Karası & 2011 & 3.63 & 13.2 & Elazı̆̆ \\
\hline 2 & Kalecik Karası-Öküzgözü & 2008 & 3.59 & 12.5 & Elazı ğ \\
\hline 3 & Öküzgözü & 2008 & 3.59 & 13.5 & Elazı̆̆ \\
\hline 4 & Karaoğlan & 2008 & 3.65 & 13.0 & Malatya (Arapgir) \\
\hline 5 & Öküzgözü-Boğazkere & 2010 & 3.33 & 12.0 & Elazığ-Diyarbakır \\
\hline 6 & Öküzgözü & 2010 & 3.55 & 13.0 & Elazı̆̆ \\
\hline 7 & Karaoğlan & 2008 & 3.67 & 13.0 & Malatya (Arapgir) \\
\hline 8 & Öküzgözü-Karaoğlan & 2008 & 3.61 & 13.0 & Malatya (Arapgir) \\
\hline
\end{tabular}




\subsection{Equipment}

Absorbance measurements were performed on a UV mini 1240 UV-Visible spectrophotometer (Shimadzu, Japan).

\subsection{Determination of Total Phenolic Content}

Spectrophotometric determination of the TPC was carried out with Folin-Ciocalteu method as adapted for wine analysis [21] using gallic acid as the standard. This method is based on the reduction of a phosphotungstenphophomolybdate complex by phenolics to blue reaction products. For the preparation of calibration curve, 0.1 $\mathrm{mL}$ aliquots of 50,100, 150, 200, 250 and $300 \mathrm{mg} / \mathrm{L}$ aqueous gallic acid solutions or $0.1 \mathrm{~mL} 20$-fold dilution samples of red wines (diluted with 13\% (v, v) ethanol) were introduced into a test tube and then $2 \mathrm{~mL}$ of $2 \%$ sodium carbonate was added. After incubation for $2 \mathrm{~min}, 0.1 \mathrm{~mL}$ of Folin-Ciocalteu's reagent (diluted with water $1: 1, \mathrm{v} / \mathrm{v}$ ) was added. After a further $30 \mathrm{~min}$ the absorbance was measured at $750 \mathrm{~nm}$ using a spectrophotometer. Results were expressed as mg gallic acid equivalents per litre of wine (mg GAE/L).

\subsection{ABTS •+ Radical-Scavenging Assay}

ABTS assay was based on a previously published method with some modifications [14], using Trolox (6-hydroxy-2,5,7,8-tetramethyl-chromane-2-carboxylic acid), a water-soluble analog of vitamin E as standard. ABTS• ${ }^{+}$ radical cation was produced by mixing $7 \mathrm{mM}$ ABTS solution and $2.46 \mathrm{mM}$ potassium persulfate aqueous solution. This stock solution was kept in the dark at room temperature for $12-16 \mathrm{~h}$ for incubation. The ABTS ${ }^{+}$solution was then diluted with ethanol (approximately 1:90, v/v) to obtain an an absorbance of $0.7 \pm 0.02$ at 734 $\mathrm{nm}$. After $100 \mu \mathrm{L}$ diluted sample or Trolox standard solution was added to $2.4 \mathrm{~mL}$ ABTS ${ }^{+}$solution, absorbance was measured at exactly 6 min. Results were expressed as Trolox-equivalent antioxidant capacity (TEAC) values $(\mathrm{mM})$. The standard curve was linear between 0 - $500 \mu \mathrm{M}$ Trolox.

\subsection{Ferric Reducing Antioxidant Power (FRAP)}

The FRAP assay was performed according to previously described method with some modifications [15]. The FRAP reagent was prepared freshly. The stock solution included $25 \mathrm{~mL}$ acetate buffer (300 mM, pH 3.6), 2.5 $\mathrm{mL} 10 \mathrm{mM}$ TPTZ (2,4,6-tripyridyl-s-triazine) solution in $40 \mathrm{mM} \mathrm{HCl}$ and $2.5 \mathrm{ml}$ of $20 \mathrm{mM} \mathrm{FeCl} 3 \cdot 6 \mathrm{H}_{2} \mathrm{O}$. The mixture was warmed at $37^{\circ} \mathrm{C}$ before using. $150 \mu \mathrm{L}$ diluted sample or Trolox standard solution was added to 2.85 mL FRAP solution. The absorbance was measured at $593 \mathrm{~nm}$ after $30 \mathrm{~min}$. Aqueous solutions of Trolox concentration were between 0 and $300 \mu \mathrm{M}$ for calibration.

\subsection{1,1-Diphenyl-2-Picrylhydrazyl Radical (DPPH•) Assay}

$6 \times 10^{-5} \mathrm{~mol} / \mathrm{L}$ of DPPH radical reagent was prepared in ethanol. $100 \mu \mathrm{L}$ of diluted wine or Trolox standard solutions were mixed with $2.9 \mathrm{~mL}$ DPPH radical solution [22] and after $30 \mathrm{~min}$, the absorbances were measured at $515 \mathrm{~nm}$ against ethanol. The standard curve was linear between 100 - $1000 \mu \mathrm{M}$ Trolox.

\subsection{Cupric Reducing Antioxidant Capacity (CUPRAC)}

Cupric reducing antioxidant capacity assay was carried out according to the method of Apak et al. [17]. $1 \mathrm{~mL}$ each of $10 \mathrm{mmM} \mathrm{Cu(II),} 7.5 \mathrm{mM}$ neocuprine, $1 \mathrm{M}$ ammonium acetate buffer (pH 7) solutions and $0.6 \mathrm{~mL}$ water were mixed in a test tube. $0.5 \mathrm{~mL}$ of diluted wine or Trolox standard solutions were added to the initial mixture. The absorbance was measured at $450 \mathrm{~nm}$ after 30 minutes. Trolox standard solutions were prepared at a concentration range from 40 to $400 \mu \mathrm{M}$.

\subsection{Statistical Analysis}

Data is expressed as means \pm SD of five paralel measurements. Correlation analysis was performed by Spearman rho coefficient. $\mathrm{p}<0.01$ was regarded as statistically significant.

\section{Results and Discussion}

\subsection{Total Phenolic Content and Total Antioxidant Capacity}

The total phenolic content (TPC) and total antioxidant capacity content (TAC) of the local wine samples are 
presented in Table 2.

TAC was measured by four different assays DPPH, ABTS, FRAP and CUPRAC using mmol Trolox equivalents per litre of wine (mmol TE/L) to express the results. The TPC of the wine samples were expressed mg of gallic acid equivalents per liter of wine (mg GAE/L).

TPC values of local wines ranged from 2599.90 to $4846.57 \mathrm{mg}$ GAE/L. The total phenolic contents determined by the Folin-Ciocalteu method for wines from other countries are as follow: M. S. Fernandez-Pachon et al. 1313 - $2389 \mathrm{mg}$ GAE/L for Spanish red wines [23]. Kallithraka et al. reported values of 621.7 - $3200.3 \mathrm{mg}$ GAE/L for Greek red wines [24]. D. Di Majo et al. reported values of 2.34 - 3.73 g/L for Sicilian red wines [25]. Minussi et al. reported values of 3314 - $4177 \mathrm{mg}$ GAE/L for Italian red wines [26]. Paixao et al. reported values of 1724 - $1936 \mathrm{mg}$ GAE/L for Portuguese red wines [5]. Stasko et al. reported values of 1460 - $3380 \mathrm{mg}$ GAE/L for Austrian and Slovakian red wines [8]. Seruga et al. reported values of 1012 - 3264 mg GAE/L for Crotian red wines [6]. Lucena et al. reported values of 3.2 - $5.9 \mathrm{~g}$ GAE/l for Brazilian red wines [10]. H. Li et al. reported values of 1402 - $3130 \mathrm{mg}$ GAE/L for selected China red wines [9]. Dugo et al. reported values of 1794 $4614 \mathrm{mg}$ GAE/L for Sicilian red wines [27]. Stratil et al. reported values of 963 - $2262 \mathrm{mg}$ GAE/L for Czech Republic red wines [12]. Jordao et al. reported values of 1788 - $3070 \mathrm{mg}$ GAE/L for Portuguese sparkling red wines [28]. Vrcek et al. reported values of 554 - $2669 \mathrm{mg} \mathrm{GAE/L} \mathrm{for} \mathrm{Crotian} \mathrm{red} \mathrm{wines} \mathrm{[11].} \mathrm{Yoo} \mathrm{et} \mathrm{al.} \mathrm{reported}$ values of 1181 - $3589 \mathrm{mg}$ GAE/L for Australian red wines [29]. Jiang et al. reported values of 860 - $2710 \mathrm{mg}$ GAE/L for selected China red wines [30]. Radovanovic et al. reported values of 1602 - 1968 mg GAE/L for selected Serbian red wines [31]. Porgalı et al. reported values of 1837 - $3467 \mathrm{mg}$ GAE/L for Turkish red wines [32] (Table 3).

Such large differences in total phenolic content between the investigated red wines from different countries are likely to result from grape varieties, vineyard location, climate, soil type, different wine processing techniques and ageing.

TAC values of local wines by DPPH, ABTS, FRAP and CUPRAC assay ranged from 7.49 - 15.93 mmol TE/L, 12.02 - $24.73 \mathrm{mmol}$ TE/L, 12.65 - $27.68 \mathrm{mmol}$ TE/L and 13.19 - 31.07 mmol TE/L, respectively (Figure 1).

The total antioxidant capacity determined by the DPPH and ABTS assay for wines from other countries are as follows: De Beer et al. reported values of 13.18 - $15.76 \mathrm{mmol}$ TE/L by ABTS assay and $9.51-12.39 \mathrm{mmol}$ TE/L by DPPH assay for South African red wines [33]. Fernandez-Pachon et al. reported values of 3.06 - 11.15 mmol TE/L by ABTS assay and 4.65 - $17.41 \mathrm{mmol}$ TE/L by DPPH assay for Spanish red wines [23]. Nixdorf et al. reported values of 2.6 - $6.3 \mathrm{mmol}$ TE/L by DPPH assay for Brazilian red wines [22]. Stasko et al. reported values of 13.22 - $17.74 \mathrm{mmol}$ TE/L DPPH assay and 7.84 - 13.59 mmol TE/L by ABTS assay for Austrian and Slovakian red wines [8]. H. Li et al. reported values of 4.19 - 17.17 mmol TE/L by DPPH assay, $9.10-30.51$ mmol TE/L by ABTS assay and 16.11 - 31.93 mmol TE/L by CUPRAC for selected China red wines [9]. Feliciano et al. reported values of 8.10 - $17.91 \mathrm{mmol}$ TE/L by FRAP assay for Portuguese wines from the Setubal Region [34]. Crotian red wines, Seruga et al. reported values of 9.2 - 37.8 mmol TE/L by DPPH assay and 7.9 $24.2 \mathrm{mmol}$ TE/L by ABTS assay for Crotian red wines [6]. Stratil et al. reported values of $2.91-8.62 \mathrm{mmol}$ TE/L by DPPH assay, 13.89 - 34.69 mmol TE/L by ABTS assay and 4.92 - 13.94 mmol TE/L by FRAP assay [12]. Vrcek et al. reported values of 4.94 - 20.64 mmol TE/L by DPPH assay and 2.87 - 11.7 by ABTS assay [11]. Jordao et al. reported values 25.60 - $37.42 \mathrm{mmol}$ TE/L by ABTS assay [28]. Yoo et al. reported values of 8.51 - $18.85 \mathrm{mmol}$ TE/L by DPPH assay for Australian red wines [29]. Jiang et al. reported values of 3.86 - 6.18 mmol TE/L by DPPH assay and 9.19 - 19.63 mmol TE/L by CUPRAC assay for selected China red wines [30]. Radovanovic et al. reported values of 3.64 - 8.06 mmol TE/L by DPPH assay for China Serbian red wines (Radovanovic et al., 2012). Xi et al. reported values of $4.73-31.05 \mathrm{mmol}$ TE/L by DPPH assay and $7.71-44.78$ mmol TE/L by ABTS assay for China red wines from Yan73 [35] (Table 4).

Different authors have reported very different Trolox equivalents values. This is expected since experimental conditions of DPPH, ABTS, FRAP and CUPRAC methods were different from each other in many details. Significant differences in antioxidant activity existed not only experimental conditions but also variety of red wines due to different origins and winemaking procedures.

\subsection{Correlation between Antioxidant Capacity and Total Polyphenols}

Correlation analysis was used to explore the relationships amongst the different antioxidant parameters measured for all wine samples (Table 5). The total phenolic contents of red wine samples exhibited a good correlation $(\mathrm{p}<0.01)$ with antioxidant properties. Amongst the methods the strong correlation between DPPH and Folin 
Table 2. Total antioxidant capacity and total phenolic content of wine samples.

\begin{tabular}{cccccc}
\hline \multirow{2}{*}{ Wines } & DPPH & ABTS & FRAP & CUPRAC & Folin \\
\cline { 2 - 6 } & $(\mathrm{mmol} \mathrm{TE} / \mathrm{L})$ & $(\mathrm{mmol} \mathrm{TE} / \mathrm{L})$ & $(\mathrm{mmol} \mathrm{TE} / \mathrm{L})$ & $(\mathrm{mmol} \mathrm{TE} / \mathrm{L})$ & $(\mathrm{mg} \mathrm{GAE} / \mathrm{L})$ \\
\hline 1 & $7.59 \pm 0.64$ & $12.02 \pm 0.69$ & $12.65 \pm 0.50$ & $13.19 \pm 1.08$ & $2599.90 \pm 219.64$ \\
2 & $7.75 \pm 0.39$ & $12.29 \pm 0.93$ & $13.46 \pm 0.51$ & $14.27 \pm 1,08$ & $2716.10 \pm 183.24$ \\
3 & $7.49 \pm 0.27$ & $12.28 \pm 0.53$ & $13.29 \pm 0.79$ & $14.11 \pm 1.09$ & $2635.14 \pm 138.62$ \\
4 & $15.93 \pm 0.55$ & $24.73 \pm 1.29$ & $27.68 \pm 1.82$ & $31.07 \pm 1.05$ & $4846.57 \pm 411.70$ \\
5 & $13.60 \pm 0.47$ & $22.29 \pm 0.56$ & $24.46 \pm 2.33$ & $27.27 \pm 1.05$ & $4704.67 \pm 388.18$ \\
6 & $13.50 \pm 0.64$ & $22.26 \pm 0.64$ & $23.58 \pm 1.55$ & $25.77 \pm 1.15$ & $4458.95 \pm 275.79$ \\
7 & $14.55 \pm 0.45$ & $22.38 \pm 0.61$ & $23.75 \pm 1.99$ & $25.81 \pm 0.72$ & $4212.29 \pm 292.84$ \\
8 & $11.31 \pm 0.99$ & $17.91 \pm 0.64$ & $18.83 \pm 1.53$ & $19.03 \pm 0.75$ & $3083.71 \pm 241.06$ \\
\hline
\end{tabular}

Data are expressed as mean values \pm SD $(n=5)$.

Table 3. Comparison of present study and published values of total phenolic content in red wines (mg gallic acid equivalents/L).

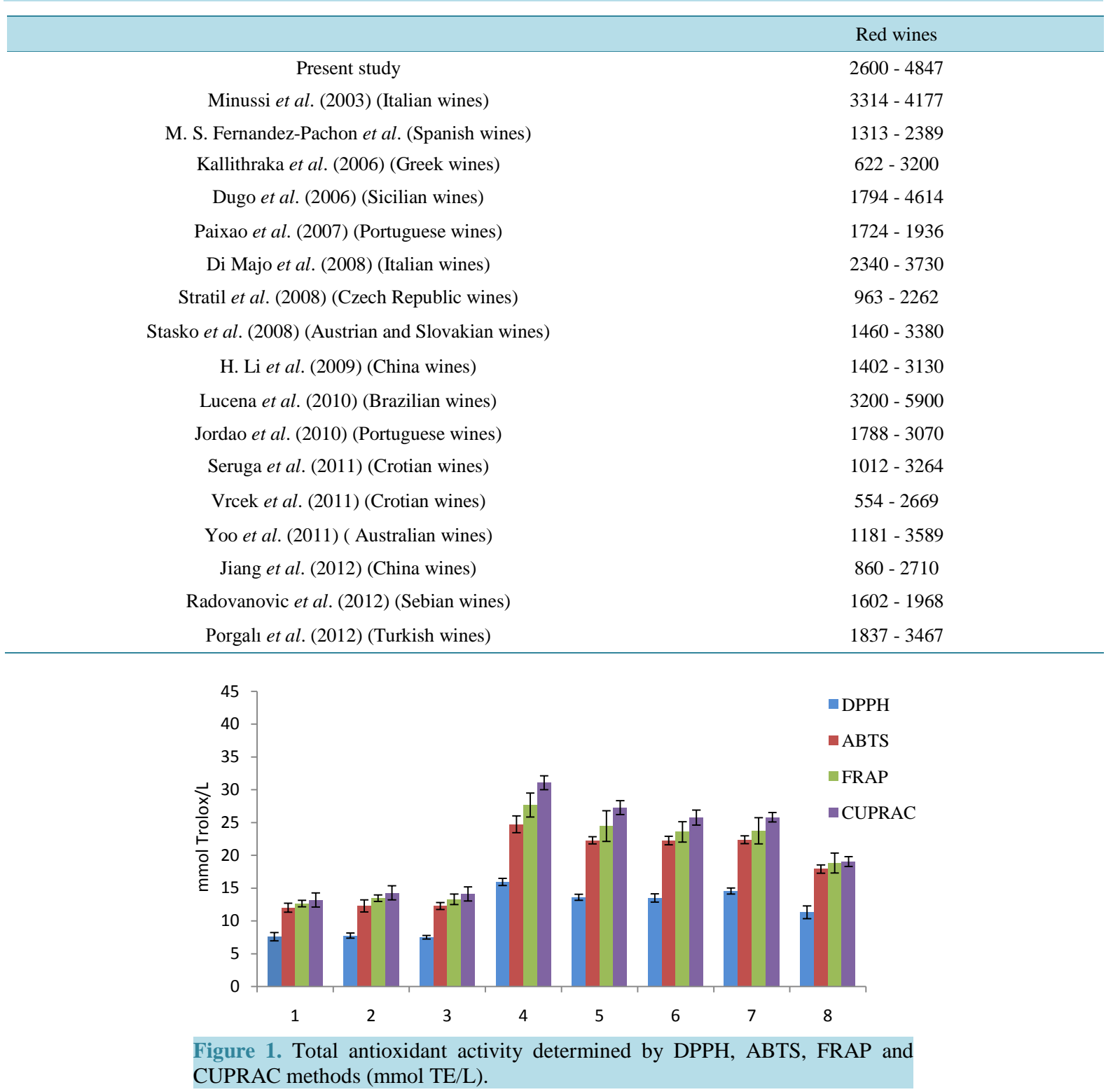


Table 4. Comparison of present study and published values of TAC by DPPH, ABTS, FRAP and CUPRAC assay in wines (mmol TE/L).

\begin{tabular}{|c|c|c|c|c|}
\hline & DPPH & ABTS & FRAP & CUPRAC \\
\hline Present study & 7.49 - 15.93 & $12.02-24.73$ & 12.65 - 27.68 & $13.19-31.07$ \\
\hline $\begin{array}{l}\text { De Beer et al. (2003) } \\
\text { (South African wines) }\end{array}$ & $9.51-12.39$ & $13.18-15.76$ & & \\
\hline $\begin{array}{l}\text { M. S. Fernandez-Pachon et al. (2004) } \\
\text { (Spanish wines) }\end{array}$ & $4.65-17.41$ & $3.06-11.15$ & & \\
\hline $\begin{array}{c}\text { Stasko et al. (2008) } \\
\text { (Austrian and Slovakian wines) }\end{array}$ & $13.22-17.74$ & $7.84-13.59$ & & \\
\hline $\begin{array}{l}\text { Stratil et al. (2008) } \\
\text { (Czech Republic wines) }\end{array}$ & $2.91-8.62$ & $13.89-34.69$ & $4.92-13.94$ & \\
\hline $\begin{array}{l}\text { H. Li et al. (2009) } \\
\text { (China wines) }\end{array}$ & $4.19-17.17$ & $9.10-30.51$ & & 16.11 - 31.93 \\
\hline $\begin{array}{l}\text { Feliciano et al. (2009) } \\
\text { (Portuguese wines) }\end{array}$ & & & 8.10 - 17.91 & \\
\hline $\begin{array}{l}\text { Nixdorf et al. (2010) } \\
\text { (Brazilian wines) }\end{array}$ & $2.6-6.3$ & & & \\
\hline $\begin{array}{l}\text { Jordao et al. (2010) } \\
\text { (Portuguese wines) }\end{array}$ & & $25.60-37.42$ & & \\
\hline $\begin{array}{l}\text { Vrcek et al. (2011) } \\
\text { (Crotian wines) }\end{array}$ & $4.94-20.64$ & $2.87-11.7$ & & \\
\hline $\begin{array}{l}\text { Seruga et al. (2011) } \\
\quad \text { (Crotian wines) }\end{array}$ & $9.2-37.8$ & $7.9-24.2$ & & \\
\hline $\begin{array}{l}\text { Yoo et al. (2011) } \\
\text { (Australian wines) }\end{array}$ & $8.51-18.85$ & & & \\
\hline $\begin{array}{l}\text { Jiang et al. (2012) } \\
\text { (China wines) }\end{array}$ & $3.86-6.18$ & & & $9.19-19.63$ \\
\hline $\begin{array}{l}\text { Radovanovic et al. (2012) } \\
\quad \text { (Serbian wines) }\end{array}$ & $3.64-8.06$ & & & \\
\hline $\begin{array}{l}\text { Xi et al. (2013) } \\
\text { (China wines) }\end{array}$ & $4.73-31.05$ & $7.71-44.78$ & & \\
\hline
\end{tabular}

Table 5. Spearman rho correlation coefficients (R) among the different methods.

\begin{tabular}{cccccc}
\hline & FOLIN & ABTS & DPPH & CUPRAC & FRAP \\
\hline FOLIN & 1.000 & $0.788^{* *}$ & $0.864^{* *}$ & $0.848^{* *}$ & $0.799^{* *}$ \\
ABTS & $0.788^{* *}$ & 1.000 & $0.863^{* *}$ & $0.829^{* *}$ & $0.870^{* *}$ \\
DPPH & $0.864^{* *}$ & $0.863^{* *}$ & 1.000 & $0.842^{* *}$ & $0.865^{* *}$ \\
CUPRAC & $0.848^{* *}$ & $0.829^{* *}$ & $0.842^{* *}$ & 1.000 & $0.886^{* *}$ \\
FRAP & $0.799^{* *}$ & $0.870^{* *}$ & $0.865^{* *}$ & $0.886^{* *}$ & 1.000 \\
\hline
\end{tabular}

${ }^{* *}$ Correlation is significant at the 0.01 level (2-tailed).

lin method was 0.864; CUPRAC and Folin method was 0.848. Amongst the methods used for quantifying antioxidant activities, the correlation between FRAP and CUPRAC; FRAP and ABTS were 0.886 and 0.870, respectively.

These results are in agreement with other reports in the literature [5] [6] [8]-[12] [30] [32].

\section{Conclusions}

Since the above methods differ from each other in terms of assay principles and reaction conditions, one single method is not enough to show all the antioxidants. Therefore this study compared four most widely used spectrophotometric methods. A good correlation between the antioxidant activities determined by DPPH, ABTS, FRAP and CUPRAC methods versus total phenol content (Folin Method) was observed for the red wines in this 
study. It has been suggested that the antioxidant capacity of wine is strongly correlated to the type of phenolic compounds present in wines. This points out the predominant role of phenols in antioxidant activity.

\section{Declarations of Interest}

Financial support from İnönü University Scientific Projects Research Unit (Project No. 2011/189) is acknowledged.

\section{References}

[1] Becker, E.M., Nissen, L.R. and Skibsted, L.H. (2004) Antioxidant Evaluation Protocols: Food Quality or Health Effects. European Food Research and Technology, 219, 561-571. http://dx.doi.org/10.1007/s00217-004-1012-4

[2] Ratnam, D.V., Ankola, D.D., Bhardwaj, V., Sahana, D.K. and Kumar, M.N.V.R. (2006) Role of Antioxidants in Prophylaxis and Therapy: A Pharmaceutical Perspective. Journal of Controlled Release, 113, 189-207. http://dx.doi.org/10.1016/j.jconrel.2006.04.015

[3] Lopez-Velez, M., Martinez-Martinez, F. and Del Valle-Ribes, C. (2003) The Study of Phenolic Compounds as Natural Antioxidants in Wine. Critical Reviews in Food Science and Nutrition, 43, 233-244. http://dx.doi.org/10.1080/10408690390826509

[4] Steffen, L.M., Jacobs, D.R., Stevens, J., Shahar, E., Carithers, T. and Folsom, A.R. (2003) Associations of WholeGrain, Refined-Grain, and Fruit and Vegetable Consumption with Risks of All-Cause Mortality and Incident Coronary Artery Disease and İschemic Stroke: The Atherosclerosis Risk in Communities (ARIC) Study. The American Journal of Clinical Nutrition, 78, 383-390.

[5] Paixao, N., Perestrelo, R., Marques, J.C. and Camara, J.S. (2007) Relationship between Antioxidant Capacity and Total Phenolic Content of Red, Rose and White Wines. Food Chemistry, 105, 204-214. http://dx.doi.org/10.1016/j.foodchem.2007.04.017

[6] Seruga, M., Novak, I. and Jakobek, L. (2011) Determination of Polyphenols Content and Antioxidant Activity of Some Red Wines by Differential Pulse Voltammetry, HPLC and Spectrophotometric Methods. Food Chemistry, 124, 12081216. http://dx.doi.org/10.1016/j.foodchem.2010.07.047

[7] Woraratphoka, J., Intarapichet, K.O. and Indrapichate, K. (2007) Phenolic Compounds and Antioxidative Properties of Selected Wines from the Northeast of Thailand. Food Chemistry, 104, 1485-1490. http://dx.doi.org/10.1016/j.foodchem.2007.02.020

[8] Stasko, A., Brezova, V., Mazur, M., Certik, M., Kalinak, M. and Gescheidt, G. (2008) A Comparative Study on the Antioxidant Properties of Slovakian and Austrian Wines. LWT_Food Science and Technology, 41, 2126-2135. http://dx.doi.org/10.1016/j.lwt.2007.11.021

[9] Li, H., Wang, X.Y., Li, Y., Li, P.H. and Wang, H. (2009) Polyphenolic Compounds and Antioxidant Properties of Selected China Wines. Food Chemistry, 112, 454-460. http://dx.doi.org/10.1016/j.foodchem.2008.05.111

[10] Lucena, A.P.S., Nascimento, R.J.B., Maciel, J.A.C., Tavares, J.X., Barbosa, J.M. and Oliveira, E.J. (2010) Antioxidant Activity and Phenolics Content of Selected Brazilian Wines. Journal of Food Composition and Analysis, 23, 30-36. http://dx.doi.org/10.1016/j.jfca.2009.08.004

[11] Vrcek, I.V., Bojic, M., Zuntar, I., Mendas, G. and Medic-Saric, M. (2011) Phenol Content, Antioxidant Activity and Metal Composition of Croatian Wines Deriving from Organically and Conventionally Grown Grapes. Food Chemistry, 124, 354-361. http://dx.doi.org/10.1016/j.foodchem.2010.05.118

[12] Stratil, P., Kuban, V. and Fojtova, J. (2008) Comparison of the Phenolic Content and Total Antioxidant Activity in Wines as Determined by Spectrophotometric Methods. Czech Journal of Food Sciences, 26, 242-253.

[13] Bondet, V., Brand-Williams, W. and Berset, C. (1997) Kinetics and Mechanisms of Antioxidant Activity Using the DPPH Free Radical Method. LWT-Food Science and Technology, 30, 609-615. http://dx.doi.org/10.1006/fstl.1997.0240

[14] Re, R., Pellegrini, N., Proteggente, A., Pannala, A., Yang, M. and Rice-Evans, C. (1999) Antioxidant Activity Applying an Improved ABTS Radical Cation Decolorization Assay. Free Radical Biology and Medicine, 26, 1231-1237. http://dx.doi.org/10.1016/S0891-5849(98)00315-3

[15] Benzie, I.F.F. and Strain, J.J. (1996) The Ferric Reducing Ability of Plasma (FRAP) as a Measure of "Antioxidant Power”: The FRAP Assay. Analytical Biochemistry, 239, 70-76. http://dx.doi.org/10.1006/abio.1996.0292

[16] Pulido, R., Bravo, L. and Saura-Calixto, F. (2000) Antioxidant Activity of Dietary Polyphenols as Determined by a Modified Ferric Reducing/Antioxidant Power Assay. Journal of Agricultural and Food Chemistry, 48, 3396-3402. http://dx.doi.org/10.1021/jf9913458 
[17] Apak, R., Guclu, K., Ozyurek, M. and Karademir, S.E. (2004) Novel Total Antioxidant Capacity İndex for Dietary Polyphenols and Vitamins C and E, Using Their Cupric İon Reducing Capability in the Presence of Neocuproine: CUPRAC Method. Journal of Agricultural and Food Chemistry, 52, 7970-7981. http://dx.doi.org/10.1021/jf048741x

[18] Cao, G.H. and Prior, R.L. (1999) Measurement of Oxygen Radical Absorbance Capacity in Biological Samples. Methods in Enzymology, 299, 50-62. http://dx.doi.org/10.1016/S0076-6879(99)99008-0

[19] Naguib, Y.M.A. (2000) A Fluorometric Method for Measurement of Oxygen Radical-Scavenging Activity of WaterSoluble Antioxidants. Analytical Biochemistry, 284, 93-98. http://dx.doi.org/10.1006/abio.2000.4691

[20] Pérez-Jiméneza, J., Arranz, S., Tabernero, M., Diaz-Rubio, M.E., Serrano, J., Goni, I. and Saura-Calixto, F. (2008) Updated Methodology to Determine Antioxidant Capacity in Plant Foods, Oils and Beverages: Extraction, Measurement and Expression of. Food Research International, 41, 274-285. http://dx.doi.org/10.1016/j.foodres.2007.12.004

[21] Matthaus, B. (2002) Antioxidant Activity of Extracts Obtained from Residues of Different Oilseeds. Journal of Agricultural and Food Chemistry, 50, 3444-3452. http://dx.doi.org/10.1021/jf011440s

[22] Nixdorf, S.L. and Hermosin-Gutierrez, I. (2010) Brazilian Red Wines Made from the Hybrid Grape Cultivar Isabel: Phenolic Composition and Antioxidant Capacity. Analytica Chimica Acta, 659, 208-215. http://dx.doi.org/10.1016/j.aca.2009.11.058

[23] Fernández-Pachón, M.S., Villano, D., Garcia-Parrilla, M.C. and Troncoso, A.M. (2004) Antioxidant Activity of Wines and Relation with Their Polyphenolic Composition. Analytica Chimica Acta, 513, 113-118. http://dx.doi.org/10.1016/j.aca.2004.02.028

[24] Kallithraka, S., Tsoutsouras, E., Tzourou, E. and Lanaridis, P. (2006) Principal Phenolic Compounds in Greek Red Wines. Food Chemistry, 99, 784-793. http://dx.doi.org/10.1016/j.foodchem.2005.07.059

[25] Di Majo, D., La Guardia, M., Giammanco, S., La Neve, L., Giammanco, M. (2008) The Antioxidant Capacity of Red Wine in Relationship with Its Polyphenolic Constituents. Food Chemistry, 111, 45-49. http://dx.doi.org/10.1016/j.foodchem.2008.03.037

[26] Minussi, R.C., Rossi, M., Bologna, L., Cordi, L., Rotilio, D., Pastore, G.M. and Duran, N. (2003) Phenolic Compounds and Total Antioxidant Potential of Commercial Wines. Food Chemistry, 82, 409-416. http://dx.doi.org/10.1016/S0308-8146(02)00590-3

[27] Dugo, G., Dugo, P., Vilasi, F., Magnisi, R., Mondello, L. and La Torre, G.L. (2006) Determination of the Polyphenolic Content in Sicilian Red Wines of Protected Geographical Indication. Italian Journal of Food Science, 18, 409-422.

[28] Jordao, A.M., Goncalves, F.J., Correia, A.C., Cantao, J., Rivero-Perez, M.D. and SanJose, M.L.G. (2010) Proanthocyanidin Content, Antioxidant Capacity and Scavenger Activity of Portuguese Sparkling Wines (Bairrada Appellation of Origin). Journal of the Science of Food and Agriculture, 90, 2144-2152.

[29] Yoo, Y.J., Prenzler, P.D., Saliba, A.J. and Ryan, D. (2011) Assessment of Some Australian Red Wines for Price, Phenolic Content, Antioxidant Activity, and Vintage in Relation to Functional Food Prospects. Journal of Food Science, 76, C1355-C1364. http://dx.doi.org/10.1111/j.1750-3841.2011.02429.x

[30] Jiang, B. and Zhang, Z.W. (2012) Comparison on Phenolic Compounds and Antioxidant Properties of Cabernet Sauvignon and Merlot Wines from Four Wine Grape-Growing Regions in China. Molecules, 17, 8804-8821. http://dx.doi.org/10.3390/molecules17088804

[31] Radovanovic, A.N., Jovancicevic, B.S., Radovanovic, B.C., Mihajilov-Krstev, T. and Zvezdanovic, J.B. (2012) Antioxidant and Antimicrobial Potentials of Serbian Red Wines Produced from International Vitis Vinifera Grape Varieties. Journal of the Science of Food and Agriculture, 92, 2154-2161. http://dx.doi.org/10.1002/jsfa.5601

[32] Porgali, E. and Buyuktuncel, E. (2012) Determination of Phenolic Composition and Antioxidant Capacity of Native Red Wines by High Performance Liquid Chromatography and Spectrophotometric Methods. Food Research International, 45, 145-154. http://dx.doi.org/10.1016/j.foodres.2011.10.025

[33] De Beer, D., Joubert, E., Gelderblom, W.C.A. and Manley, M. (2003) Antioxidant Activity of South African Red and White Cultivar Wines: Free Radical Scavenging. Journal of Agricultural and Food Chemistry, 51, 902-909. http://dx.doi.org/10.1021/jf0260110

[34] Feliciano, R.P., Bravo, M.N., Pires, M.M., Serra, A.T., Duarte, C.M., Boas, L.V. and Bronze, M.R. (2009) Phenolic Content and Antioxidant Activity of Moscatel Dessert Wines from the Setubal Region in Portugal. Food Analytical Methods, 2, 149-161. http://dx.doi.org/10.1007/s12161-008-9059-7

[35] Xi, Z.M., Meng, J.F., Huo, S.S., Luan, L.Y., Ma, L.N. and Zhang, Z.W. (2013) Exogenously Applied Abscisic Acid to Yan73 (V. vinifera) Grapes Enhances Phenolic Content and Antioxidant Capacity of Its Wine. International Journal of Food Sciences Nutrition, 64, 444-451. http://dx.doi.org/10.3109/09637486.2012.746291 
Scientific Research Publishing (SCIRP) is one of the largest Open Access journal publishers. It is currently publishing more than 200 open access, online, peer-reviewed journals covering a wide range of academic disciplines. SCIRP serves the worldwide academic communities and contributes to the progress and application of science with its publication.

Other selected journals from SCIRP are listed as below. Submit your manuscript to us via either submit@scirp.org or Online Submission Portal.
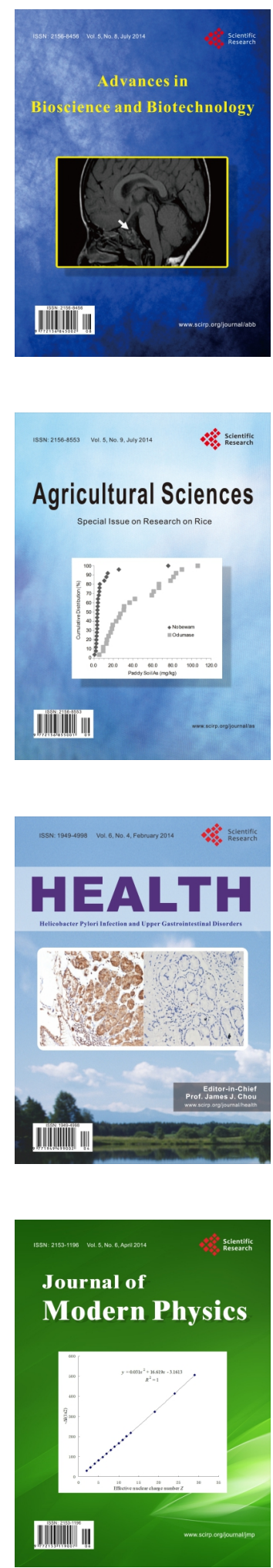
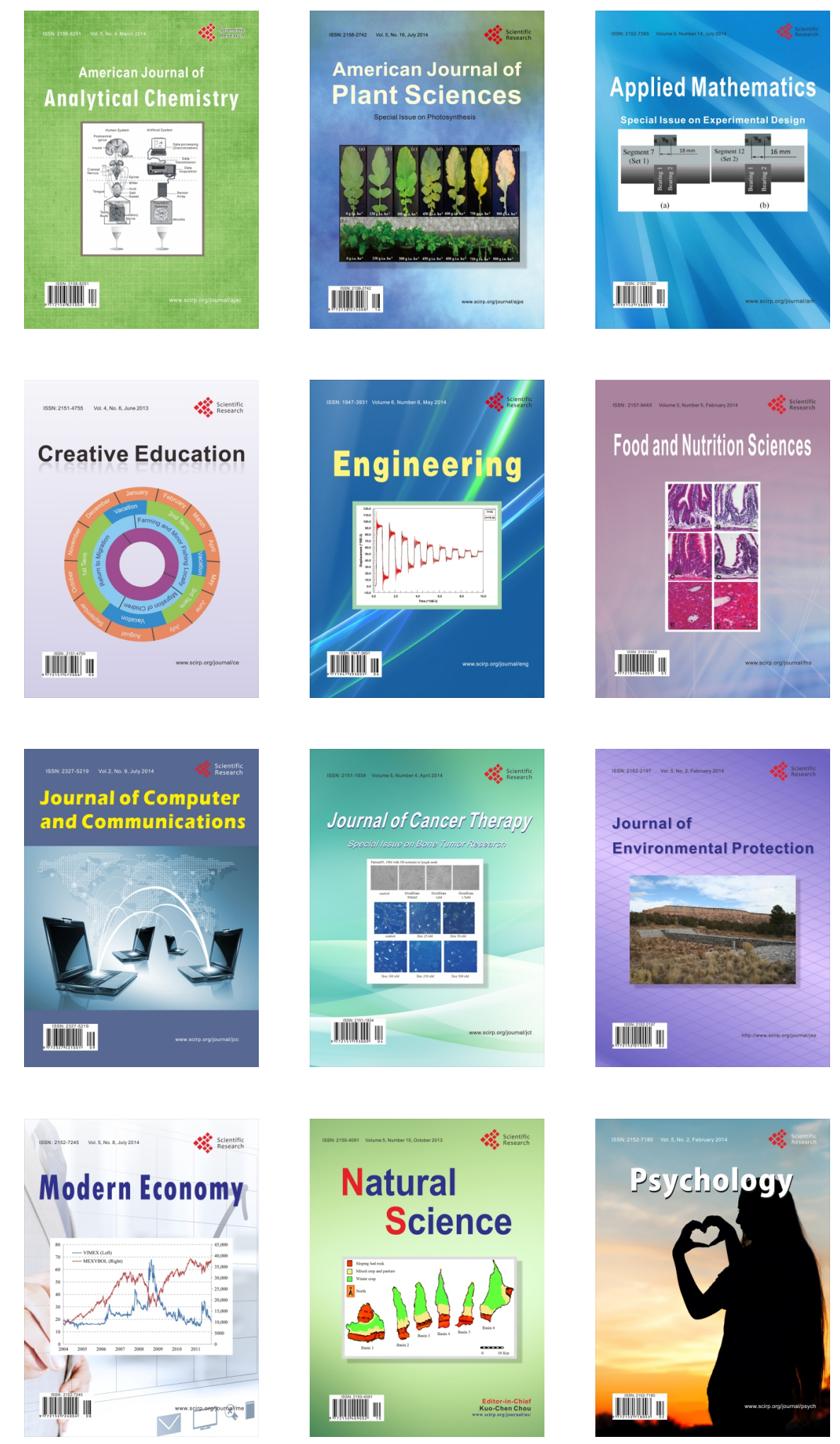